\title{
TALLINN RADIOCARBON DATES I
}

\section{J. M. PUNNING, T. KAKUM, and R. RAJAMÄE}

Institute of Geology, Academy of Sciences, Estonian SSR

Preparations for determining absolute age by the radiocarbon method were started at the Institute of Geology, Academy of Sciences of the Estonian SSR in 1971. Dating of samples has been carried out since 1972.

The measurement of natural $\mathrm{C}^{14}$ activity is performed by a liquid scintillation method. Benzene is used as the carrier of natural $\mathrm{C}^{14}$ activity. Benzene is synthesized through lithium carbide with its subsequent decomposition in water and by trimerization of acetylene by means of the alumosilicate-vanadium catalyst of Arslanov and Gromova (1967). The benzene yield (calculated on the basis of $\mathrm{C}_{2} \mathrm{H}_{2}$ ) is ca. $95 \%$.

Counting of natural $\mathrm{C}^{14}$ is done with 1-channel and 2-channel scintillation devices, (Punning, and Rajamäe, 1973).

Wood dating from A.D. $1850 \pm 10$ years is used as a reference standard of modern carbon. All radiocarbon dates were based on a half-life for $\mathrm{C}^{14}$ of $5568 \pm 30$ years. Results are reported in years before 1950 .

\section{GEOLOGIC SAMPLES}

\section{TIn-1.}

$$
1320 \pm 70
$$

A.D. 630

Remains of wood used as check sample for interlaboratory control. Comment: sample dated by laboratory of the Leningrad State Univ. as LU-108: $1350 \pm 70$.

\section{Tln-2. Crimea-1}

$1675 \pm 50$

Wheat grains from Tarhakut Peninsula, Crimea, from ancient town of Hersonesos. Coll. and subm. 1970 by L. Firsov, Inst. Geol. and Geophysics, Siberian Dept., Acad. Sci. USSR. Comment: dated as SOAN232: $1780 \pm 50$.

\section{Tln-3. Crimea-2}

$$
1670 \pm 50
$$

Same sample as Tln-2. Benzene synthesized by L. Firsov.

\section{A.D. 280}

Tln-4. Ventspils

$9025 \pm 75$

7075 B.c.

Wood from left bank of R. Venta, near Ventspils, Latvian SSR. Coll. at depth $4 \mathrm{~m}$. Sediments overlain by a barrier beach from an $A n$ cylus transgression in Boreal time. Coll. 1971 and subm. by H. Kessel, J. M. Punning, and R. Rajamäe, Inst. Geol., Acad. Sci. Estonian SSR (now Inst. Geol.).

\section{Tln-7. Rezekne-1}

Plant remains near Burzava R.R. Sta. in Rezekne Dist., Latvian SSR. Sample coll. from hill slope at depth $20 \mathrm{~cm}$. Aleurite containing 
plant remains is buried under reddish-brown till. Coll. 1970 and subm. by Meirons, Geol. Board, Latvian SSR.

TIn-8. Rezekne-2

$10,860 \pm 140$

Plant remains from same complex as Tln-7. Sample coll. at depth $10 \mathrm{~cm}$.

Tln-9. Rezekne-3

$7945 \pm 250$ 5995 B.C. $5 \mathrm{~cm}$.

Plant remains from same complex as Tln-7. Sample coll. at depth

\section{Gipka series}

Gipka profile is on W shore of Riga Bay, $\mathrm{N}$ of Gipka, Latvian SSR. Samples coll. 197I and subm. by H. Kessel.

\section{Tln-10. Gipka}

$8895 \pm 85$

6945 B.c.

Reed and sedge peat at depth 280 to $290 \mathrm{~cm}$. Peat accumulated at end of Pre-Boreal climatic period, at time of regression of Baltic Sea.

\section{Tln-13. Gipka}

Coarse detritic sapropel at depth 100 to $105 \mathrm{~cm}$.

\section{Tln-22. Gipka}

$4060 \pm 50$ under Littorina Sea sands.

\section{TIn-11. Rebase}

$8970 \pm 70$

Sedge peat with remains of Bryales ca, $20 \mathrm{~km}$ S of Tartu. Sample coll. at depth 220 to $230 \mathrm{~cm}$, from contact zone of peat, sandy loam layers. Coll. 1971 and subm. by R. Karukäpp, Inst. Geol.

\section{Tln-12. Svetupe}

$5510 \pm 65$

\section{B.C.}

Coarse detritic sapropel from E beach of Riga Bay, near Salatsgriva, Latvian SSR. Organic sediments in profile overlain by beach gravel and eolian sands at time of transgression of Littorina Sea. Sample coll. 1970, at depth 435 to $445 \mathrm{~cm}$, and subm. by H. Kessel.

\section{Tln-26. Svetupe}

Sample from same complex as Tln-12, from upper layer of coarse detritic sapropel. Coll. at depth 420 to $425 \mathrm{~cm}$. Accumulation of lower gravel and eolic sands proceeded at time of Sub-Boreal transgression of Baltic $\left(\mathrm{L}_{V}\right.$ by Berglund, 1971). 


\section{Tln-14. Neeruti}

Peat with wood remains $2 \mathrm{~km} \mathrm{~S}$ of Kadrina R.R. Sta., Estonian SSR. Sample from lower part of peat complex below sandy loams, at depth 490 to $505 \mathrm{~cm}$. Coll. 1971 and subm. by R. Karukäpp.

$4150 \pm 60$

\section{Tln-15. Plyussa} 2200 B.C.

Peat with wood remains in flood-plain sediments of Plyussa R., Slantsy Dist. Russian SFSR. Sample coll. from ancient sediments at depth 360 to $365 \mathrm{~cm}$. Coll. 1970 and subm. by A. Miidel and U. Paap, Inst. Geol.

\section{Tula series}

Peat bog is on the lst terrace of the valley flat of Medvyanka $R$. near Tula, Russian SFSR. Samples from vertical wall of prospecting shaft. Samples coll. 1971 and subm. by T. Serebryannaya, Inst. Geog., Acad. Sci. USSR (now Inst. Geog.).

\section{Tln-18. Tula-37}

$2540 \pm 40$

Dark brown, well-decomposed peat at depth 225 to $230 \mathrm{~cm}$.

\section{Tln-19. Tula-37}

$5560 \pm 60$

Dark gray peat at depth 245 to $250 \mathrm{~cm}$.

\section{B.C.}

\section{Tln-20. Tula-37}

$9290 \pm 100$

7340 B.C.

Wood and sedge peat with fragments of shells at depth 330 to $335 \mathrm{~cm}$.

\section{Tln-21. Tula-37}

$9320 \pm 80$

Dark gray peat with fragments of shells at depth 340 to $345 \mathrm{~cm}$.

\section{Tln-29. Tula-38}

Wood peat at depth 60 to $65 \mathrm{~cm}$.

\section{Tln-30. Tula-38}

Well-decomposed peat at depth 115 to $120 \mathrm{~cm}$.

\section{Tln-31. Tula-38}

Well-decomposed peat at depth 170 to $180 \mathrm{~cm}$.
$1100 \pm 60$

A.D. 750

$2265 \pm 60$

315 B.c.

$3740 \pm 60$ 1790 в.C. 
Peat in outwash deposits on E coast of W Spitzbergen. Sample coll. from a terrace at height $22 \mathrm{~m}$. Coll. 1966 and subm. by L. Troitski, Inst. Geog.

\section{Tln-25. Polar Ural}

$$
9860 \pm 75
$$

7910 B.C.

Remains of wood from ancient lake sediments from bank of Bolshaya Lagorta R. Organogenic deposits are embedded over sandy clay at depth $550 \mathrm{~cm}$. Sample coll. 1971 and subm. by L. Troitski.

\section{TIn-28. Usa}

$6760 \pm 75$

4810 B.C.

Peat on 1st terrace of Usa R., opposite mouth of Seida R., Komi ASSR. Height of terrace 700 to $750 \mathrm{~cm}$. Peat overlies light gray clays, and is overlain by sandy loams. Sample from depth $300 \mathrm{~cm}$. Coll. 1971 and subm. by L. Troitski.

\section{Tln-33. Tuudi}

$7860 \pm 70$

5910 в.с.

Sapropel with remains of Sphagnum, SW of v. Lihula, Haapsalu Dist., Estonian SSR. Sapropel, buried under Littorina sands, overlies aleurite. Sample from lower part of sapropel. Coll. 1972 and subm. by H. Kessel. Pollen analysis performed by $\mathrm{H}$. Kessel refers lower part of sapropel to Pollen Zone AT1 (Nilsson, 1961).

\section{Tln-34. Kääsla}

$$
\begin{aligned}
& 6420 \pm 60 \\
& 4470 \text { в. . }
\end{aligned}
$$

Sapropel on E slope of Central Upland of I. Saaremaa. The spit from an Ancylus transgression formed a lagoon which is now peat. Sample from lower part of sapropel below lacustrine marl. Coll. 1972 and subm. by J. M. Punning. Pollen analysis performed by H. Kessel refers the lower part of sapropel to Pollen Zone AT 1 (Nilsson, 1961).

\section{Tln-35. Kurenurme}

$12,420 \pm 90$

Plant remains from bore-hole at depth 500 to $750 \mathrm{~cm}$ from Kurenurme in Vôru Dist., Estonian SSR. Coll. 1972 and subm. by J. M. Punning. Comment: absolute age of sample TA-57 from same deposit previously dated as $12,650 \pm 500$ (R., 1966, v. 8, p. 430-441). Date indicates that these intermoraine deposits accumulated at time of $\mathrm{B} \phi$ lling interstadial (Punning et al., 1968).

\section{TIn-36. Dridzaluki}

$18,020 \pm 100$

Plant remains on left bank Usvyach R., near v. Dridzaluki, Byelorussian SSR. Sample from depth $120 \mathrm{~cm}$ under till. Coll. 1972 and 
subm. by J. M. Punning, R. Rajamäe, and L. Smirnova. Comment: $\mathrm{C}^{14}$ date by Leningrad State Univ. $\mathrm{C}^{14}$ lab. is: LU-(95-A, 17,770 \pm 170 (Voznyaczyk, 1972).

$$
\text { II. ARCHAEOLOGIC SAMPLES }
$$

Kuressaare Castle series

$360 \pm 50$

Tln-5. Kuressaare

A.D. 1590

Charcoal from excavations of Kuressaare Castle, Kingissepa Dist., I. Saaremaa, Estonian SSR. Traces of wooden structure at depth $50 \mathrm{~cm}$. Coll. 1971 and subm. by J. Selirand, Inst. Hist., Acad. Sci., Estonian SSR. (now Inst. Hist.).

$\mathbf{3 1 5} \pm \mathbf{5 0}$

TIn-6. Kuressaare

A.D. 1635

Charcoal near $\mathrm{E}$ tower of castle, from depth $150 \mathrm{~cm}$, underlying clay. Coll. 1971 and subm. by J. Selirand.

Tln-37. Kuressaare

$655 \pm 50$

Relic from E tower of castle. Coll. 1972 and subm. by K. Aluvee.

Tln-38. Kuressaare

A.D. 1460

$490 \pm 50$

Charcoal. Traces of wooden structure near S tower. Coll. 1972 and subm. by K. Aluvee.

\section{Alatskivi series}

Tln-16. Alatskivi

$1460 \pm 50$

Charcoal from excavations of an ancient stronghold, "The Bed of Kalevipoeg”, Tartu Dist., near v. Alatskivi on E coast of Peipsi Lake, Estonian SSR. Traces of wooden structure, probably for defense. Coll. 1971 and subm. by M. Aun, Inst. Hist.

\section{TIn-17. Alatskivi}

$1560 \pm 50$

Charcoal from cultural layer in SW part of stronghold. Coll. 1971 and subm. by M. Aun.

\section{Tln-23. Alatskivi}

$2200 \pm 50$

350 B.c.

Charcoal from cultural layer of 1st period of settlement. Coll. 1971 and subm. by M. Aun. Presumed archaeol. age: 2nd half of 1st millennium B.c.

Tln-27. Alatskivi

$2060 \pm 50$

Charcoal from cultural layer of 1st period of settlement. Coll. 1971 and subm. by M. Aun. 


\section{REFERENCES}

Arslanov, H. A. and Gromova, L. J.. 1967: Author's Certificate 1136238/23-4, Sept. 26,1967 .

Berglund, B. E., 1971, Littorina transgression in Blekinge, South Sweden. A preliminary survey: Geol. Fören. Stockholm Förh., v. 93, p. 625-652.

Liiva, A., Ilves, E., and Punning, J. M., 1966, Tartu radiocarbon dates I: Radiocarbon, v. 8 , p. $430-441$.

Nilsson, T., 1961, Ein neues Standardpollendiagramm aus Bjärojöholmssjoon in Schonen: Lunds Univ. Arsskrift, N.E. Avd. 2, v. 56, no. 18.

Punning, J. M. and Rajamäe, R., 1973, Determination of the natural $\mathrm{C}^{14}$ by onechannel scintillation computer at the Geological Institute of the Academy of Sciences of the ESSR.: ENSV TA Toimetised, Keemia-Geol., v. 22, no. 1, p. 91-94.

Punning, J. M. K. et al., 1968, Paleogeografitscheskie osobennosti i absoljutnôi vozrast luzschkoi stadii valdaiskogo oledenenija na Russkoi ravnine: Dokl. Akad. Nauk SSSR, v. 178, p. 916-918.

Vaznjacuk, L. N., 1972, Vozrast maksimalnoi stadii valdaiskogo oledenenija na severozapade SSSR i osnovnyc fazy degradazii lednika: Voprosy cetverticnoi geol., v. 6 , p. 29-43. 